\title{
Durability of Recycled Concrete Aggregate in
}

\section{Aggressive Environments}

\author{
Zainab Aamer Shamsulddin \\ College of Engineering, Al-Iraqia University, Baghdad 10001, Iraq
}

\begin{abstract}
The main purpose of this research is to study the durability of recycled concrete as a partial replacement of coarse aggregate in corrosive environment. $10 \%, 20 \%, 30 \%$ and $40 \%$ by weight were used for recycled concrete. Concrete samples exposed to $10 \%$ concentration dilute sulfuric acid solution for 180 days. Mechanical tests such as compressive and tensile strength tests, physical tests such as ultrasonic pulse velocity, bulk density, porosity, specific gravity and water absorption tests were done to the samples after curing in normal water for 28 days and after submerged in dilute sulfuric acid for 180 days. Degradation increased with increasing of replacement. Test results showed that $10 \%$ and $20 \%$ partial replacement of recycled concrete aggregate still closely to reference samples. Noticeable deterioration was shown in mechanical and physical properties for $30 \%$ and $40 \%$ partial replacement of recycled concrete aggregate.
\end{abstract}

Key words: Recycled concrete, sulfuric acid, compressive strength, tensile strength, durability, partial replacement.

\section{Introduction}

Rapid industrial development causes serious problems all over the world such as depletion of natural aggregates and creates enormous amounts of waste materials from construction and demolition activities. One of the ways to reduce this problem is to utilize recycled concrete aggregate in the production of concrete [1]. At ambient temperature, using of recycled concrete as a partial coarse aggregate replacement in proportions $10 \%, 20 \%$ and $30 \%$ gives a best mechanical and physical properties test results [2]. Sulfuric acid is one of destructive acids to concrete and depending on its concentration and formation manner, can cause severe degradation and damage to the concrete structures with which it comes into contact. In steel iron industry, waste acids which are used for surface preparations may be disposed in waste water systems which will consequently result in attacks to underground concrete facilities [3]. Also certain bacteria convert sewage into sulfuric acid. Acids react

Corresponding author: Zainab Aamer Shamsulddin, assistant professor, research fields: sustainable construction materials. with calcium hydroxide of the hydrated Portland cement [4]. Acids generally attack and leach away the calcium compounds of the paste, they may not readily attack certain aggregate such as siliceous aggregates [5]. Sulfuric acid reacts with free lime and forms gypsum; wet-dry cycles of exposure to sulfuric acid increase the degree of concrete deterioration [6].

\section{Experimental Works}

\subsection{Materials}

Local sulfate resistance Portland cement type (I) was used in the mixes. Chemical and physical tests of cement are illustrated in Tables 1 and 2. The results showed that cement chemical analysis specify ASTM (American Society for Testing and Material) C114-07 [7].

Local sand was used as a fine aggregate in all mixes, sieve analysis test results illustrated in Table 3 and specify ASTM C136-01 [8]. Laboratory tests showed that specific gravity, water absorption and sulfates contents for fine aggregate are $2.6 \%, 1.6 \%$ and $0.27 \%$, respectively.

Local gravel was used as a coarse aggregate and specify ASTM C136-01 [8] with maximum grain size 
Table 1 Chemical analysis of cement.

\begin{tabular}{ll}
\hline Compound type & Results (\%) \\
\hline $\mathrm{SiO}_{2}$ & 22.041 \\
$\mathrm{Al}_{2} \mathrm{O}_{3}$ & 3.531 \\
$\mathrm{Fe}_{2} \mathrm{O}_{3}$ & 3.783 \\
$\mathrm{CaO}$ & 63.21 \\
$\mathrm{MgO}$ & 2.282 \\
$\mathrm{SO}_{3}$ & 2.401 \\
L.O.I & 0.643 \\
I.R & 0.97 \\
L.S.R & 0.89 \\
$\mathrm{C}_{3} \mathrm{~A}$ & 1.7 \\
\hline
\end{tabular}

Table 2 Physical properties of cement.

\begin{tabular}{ll}
\hline Properties & Results \\
\hline Initial setting time & $122 \mathrm{~min}$ \\
Final setting time & $176 \mathrm{~min}$ \\
Soundness & $1 \mathrm{~mm}$ \\
Compressive strength at 3 days & $26.6 \mathrm{~N} / \mathrm{mm}^{2}$ \\
Compressive strength at 7 days & $43 \mathrm{~N} / \mathrm{mm}^{2}$ \\
\hline
\end{tabular}

Table 3 Sieve analysis of sand.

\begin{tabular}{ll}
\hline Sieve size $(\mathrm{mm})$ & Passing $(\%)$ \\
\hline 9.5 & 100 \\
4.75 & 95 \\
2.36 & 93 \\
1.18 & 79 \\
0.6 & 61 \\
0.3 & 28 \\
0.15 & 0 \\
\hline
\end{tabular}

$10 \mathrm{~mm}$. Laboratory tests showed that specific gravity, water absorption and sulfates contents for coarse aggregate are $2.64 \%, 0.9 \%$ and $0.07 \%$, respectively.

Reference concrete samples were crushed and used as a partial replacement recycled coarse aggregate $10 \%$, $20 \%, 30 \%$ and $40 \%$ by weight with maximum grain size $10 \mathrm{~mm}$.

\subsection{Materials Preparations}

Concrete prepared for reference samples with mix proportion 1:2:4 (C:S:G (cement:sand:gravel)) by weight and $w / c$ ratio 0.5 to obtain slump equal to $40 \mathrm{~mm}$ [9].

Reference concrete samples were reused as recycled coarse aggregates after crushing and sieving in proportions $10 \%, 20 \%, 30 \%$ and $40 \%$ by weight of coarse aggregate. Concrete mix proportion is 1:2:4 (C:S:G \& RCA (recycled concrete aggregate)) with $w / c 0.52$ to obtain slump equal to $40 \mathrm{~mm}$ [9].

\subsection{Samples Casting and Curing}

Steel cubes with $150 \mathrm{~mm}$ size and steel prisms (400 $\times 100 \times 100) \mathrm{mm}$ size were used to cast concrete specimens. Perfect compaction was achieved by using compacting vibrating table; concrete surface was leveled and covered by using polyethylene sheet for $24 \mathrm{~h}$ in ambient laboratory temperature $37{ }^{\circ} \mathrm{C}$. Specimens cured in drinking water for 28 days and used in this experimental study (Fig. 1).

\subsection{Samples Mechanical and Physical Tests}

\subsubsection{Compressive Strength}

This test was done according to BS 1881: Part 1161983 [10] for concrete cubes and the results represent average results of two cubes.

\subsubsection{Tensile Strength}

This test was done according to ASTM C293-02 [11] for concrete prisms $(400 \times 100 \times 100) \mathrm{mm}$ and the results represent average results of two prisms.

\subsubsection{Ultrasonic Pulse Velocity}

This test was done according to ASTM C597-02 [12] for concrete cubes and the results represent average results of two cubes.

\subsubsection{Bulk Density}

This test was done according to ASTM C642-97 [13] for concrete cubes and the results represent average results of two cubes.

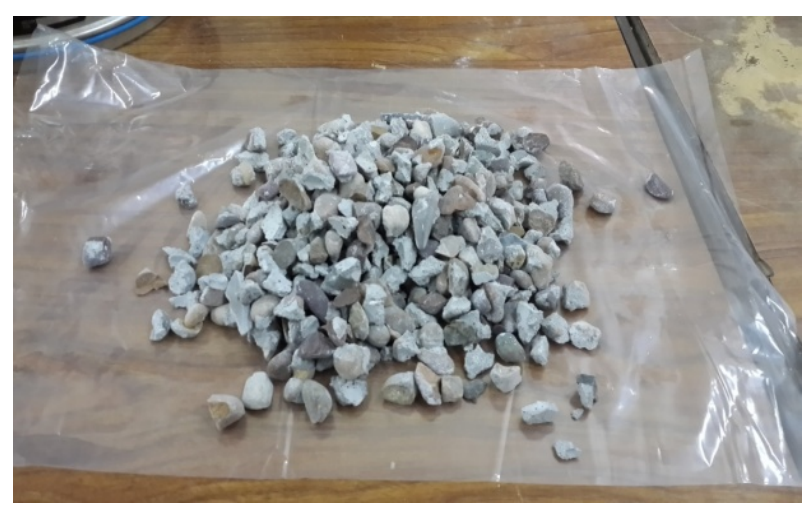

Fig. 1 Recycled concrete aggregate. 


\subsubsection{Apparent Specific Gravity}

This test was done according to ASTM C642-97 [13] for concrete cubes and the results represent average results of two cubes.

\subsubsection{Apparent Porosity}

This test was done according to ASTM C642-97 [13] for concrete cubes and the results represent average results of two cubes.

\subsubsection{Water Absorption}

This test was done according to ASTM C642-97 [13] for concrete cubes and the results represent average results of two cubes.

\subsubsection{Slump Test}

This test was done according to ASTM C143-01 [9] for all concrete mixtures and the average result equals to $40 \mathrm{~mm}$.

\section{Results and Discussion}

The results of water curing samples indicated that compressive and flexural tensile strength for reference concrete samples with natural aggregate higher than for concrete with different recycled aggregates proportions. Maximum cube compressive strength is $31.3 \mathrm{MPa}$ and flexural tensile strength is $3.5 \mathrm{MPa}$ for reference samples.
Recycled concrete aggregate replacement in amounts $10 \%, 20 \%, 30 \%$, and $40 \%$ decrease compressive and flexural tensile strength of water curing concrete, cube compressive strength and flexural tensile strength test results range respectively between $30.66 \mathrm{MPa}, 3.1 \mathrm{MPa}$ for $10 \%$ replacement to 24.22 MPa, 2.5 MPa for $40 \%$ replacement as shown in Table 4, Figs. 2 and 3. The reduction in compressive and flexural tensile strength may be due to a poor bond between cement paste and recycled aggregate particles which contain hydrated cement paste particles.

Compressive strength is a major indicator for many physical properties of concrete such as UPV (ultrasonic pulse velocity), bulk density, apparent specific gravity, porosity and water absorption. Increasing the compressive strength value means increasing the bulk density, specific gravity and UPV value and decreasing the porosity and water absorption percentage. UPV test results are $5.41 \mathrm{~km} / \mathrm{s}$ for reference samples and range between $5.06 \mathrm{~km} / \mathrm{s}$ to $5.37 \mathrm{~km} / \mathrm{s}$ for recycled concrete aggregate replacement in proportions $(10 \%$ to $40 \%)$ as shown in Table 5 and Fig. 4.

Bulk density test results are $2.309 \mathrm{~g} / \mathrm{cm}^{3}$ for reference samples and range between $2.22 \mathrm{~g} / \mathrm{cm}^{3}$ to

Table 4 Compressive and flexural tensile strength of recycled concrete in water $\left(\mathbf{N} / \mathbf{m m}^{2}\right)$.

\begin{tabular}{|c|c|c|}
\hline Type of samples & Type of test Compressive strength (MPa) & Flexural tensile strength $(\mathrm{MPa})$ \\
\hline Reference concrete & 31.3 & 3.5 \\
\hline $10 \% \mathrm{RC}$ replacement & 30.66 & 3.1 \\
\hline $20 \%$ RC replacement & 29.2 & 3.0 \\
\hline $30 \% \mathrm{RC}$ replacement & 27.6 & 2.9 \\
\hline $40 \% \mathrm{RC}$ replacement & 24.22 & 2.5 \\
\hline
\end{tabular}

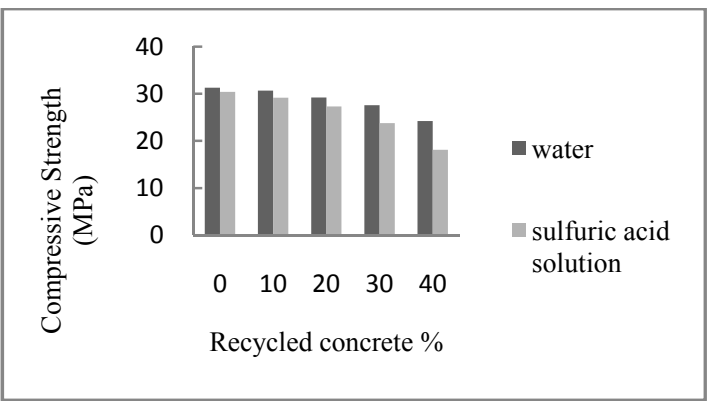

Fig. 2 Compressive strength results.

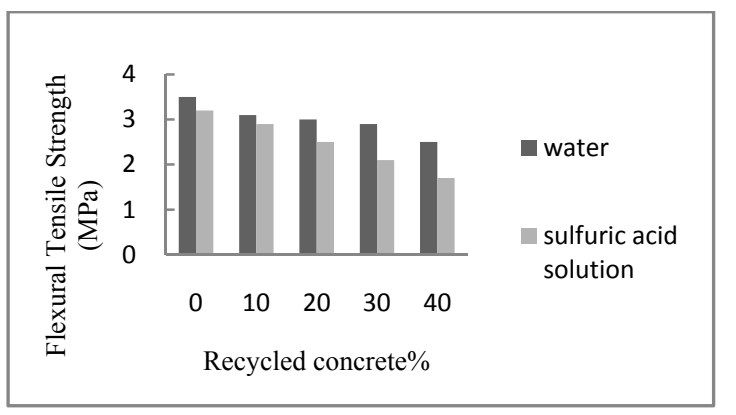

Fig. 3 Flexural tensile strength results. 
$2.302 \mathrm{~g} / \mathrm{cm}^{3}$ for recycled concrete aggregate replacement in proportions (10\% to $40 \%$ ) as shown in Table 5 and Fig. 5.

Water absorption test results are $3.972 \%$ for reference samples and range between $3.977 \%$ to $3.991 \%$ for recycled concrete aggregate replacement in proportions (10\% to $40 \%$ ) as shown in Table 5 and Fig. 6.

Specific gravity test results are 2.538 for reference samples and range between 2.489 to 2.528 for recycled concrete aggregate replacement in proportions (10\% to 40\%) as shown in Table 5 and Fig. 7.

Porosity test results are $8.993 \%$ for reference samples and range between $9.370 \%$ to $10.98 \%$ for recycled concrete aggregate replacement in proportions (10\% to $40 \%$ ) as shown in Table 5 and Fig. 8.

Sulfuric acid is particularly aggressive because, in the addition to the sulfate attack of the aluminates phase, acid attack on $\mathrm{Ca}(\mathrm{OH})_{2}$ and C-S-H takes place [14].

Dilute sulfuric acid is the main cause of concrete compressive strength deterioration because of the

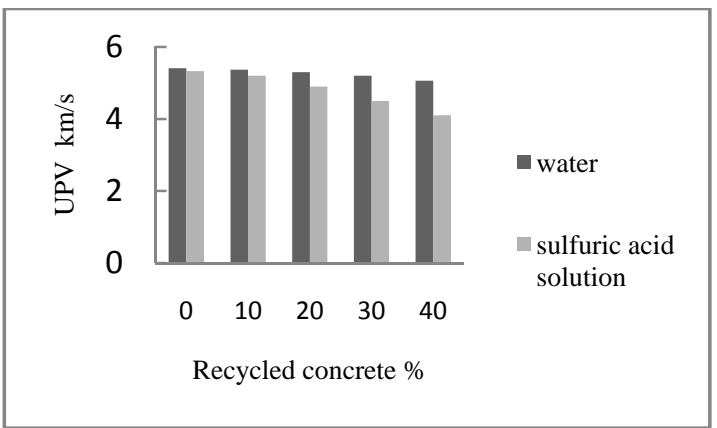

Fig. 4 UPV results.

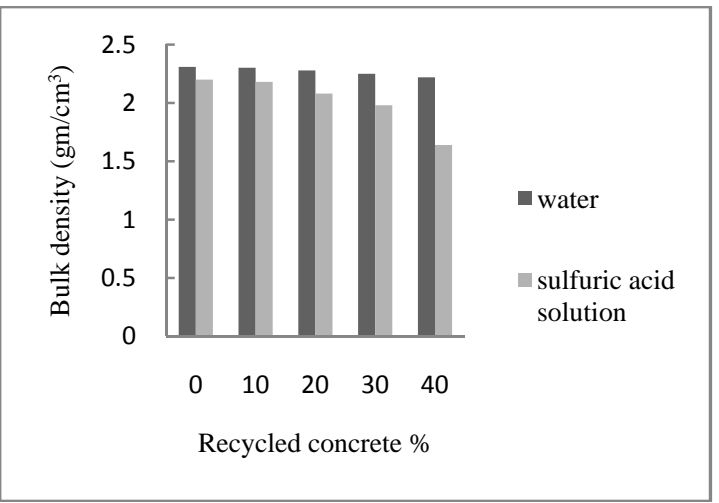

Fig. 5 Bulk density results.

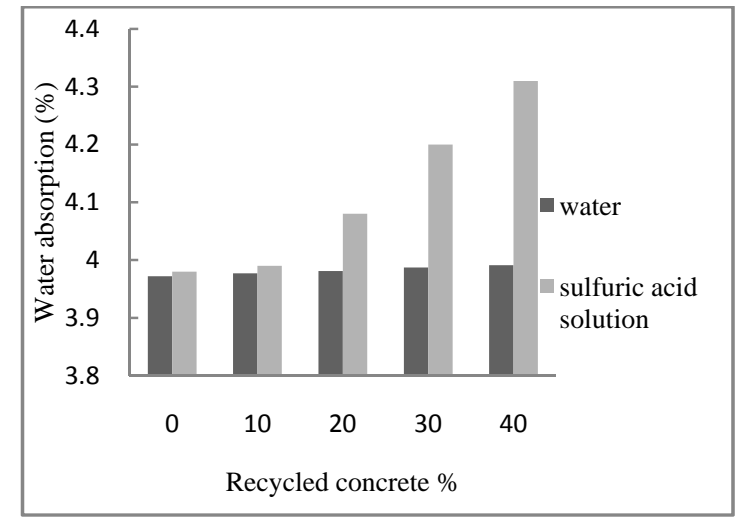

Fig. 6 Water absorption results.

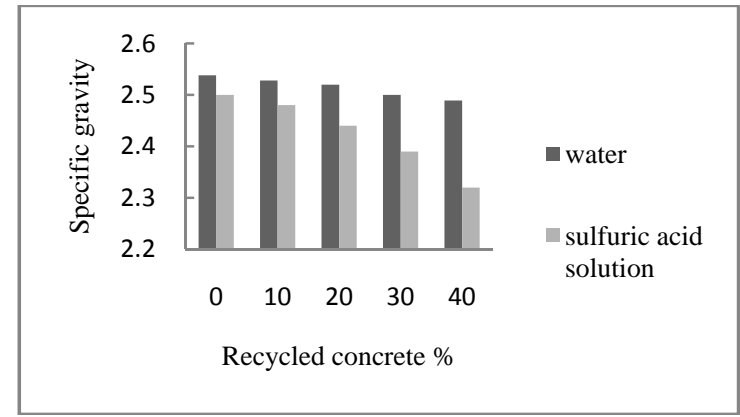

Fig. 7 Specific gravity results.

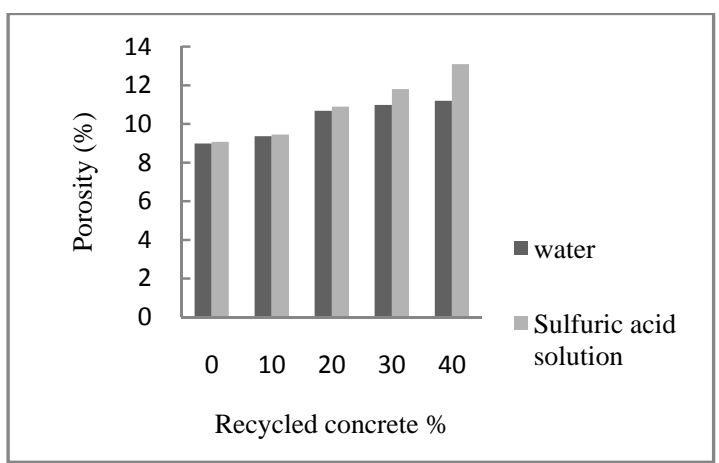

Fig. 8 Porosity results.

decomposition of calcium silicate hydrate compound [15].

The results of immerged samples in dilute sulfuric acid solution is lower than water curing samples.

The results of immerged samples in dilute sulfuric acid solution as shown in Table 6 indicated that compressive and flexural tensile strength for reference concrete samples with natural aggregate is higher than for concrete with different recycled aggregates proportions. Maximum cube compressive strength is 30.4 $\mathrm{MPa}$ and flexural tensile strength is $3.2 \mathrm{MPa}$ for reference samples. 
Table 5 Physical tests of recycled concrete samples in water.

\begin{tabular}{|c|c|c|c|c|c|c|}
\hline Type of samples & Test type of & U.P.V. (km/s) & $\begin{array}{l}\text { Bulk density } \\
\left(\mathrm{gm} / \mathrm{cm}^{3}\right)\end{array}$ & $\begin{array}{l}\text { Water absorption } \\
(\%)\end{array}$ & Specific gravity & Porosity (\%) \\
\hline Reference concrete & & 5.41 & 2.309 & 3.972 & 2.538 & 8.993 \\
\hline 10 \% RC replacement & & 5.37 & 2.302 & 3.977 & 2.528 & 9.370 \\
\hline 20 \% RC replacement & & 5.3 & 2.278 & 3.981 & 2.520 & 10.678 \\
\hline 30 \% RC replacement & & 5.2 & 2.250 & 3.987 & 2.50 & 10.98 \\
\hline 40 \% RC replacement & & 5.06 & 2.22 & 3.991 & 2.489 & 11.2 \\
\hline
\end{tabular}

Table 6 Compressive and flexural strength in acid $\left(\mathrm{N} / \mathrm{mm}^{2}\right)$.

\begin{tabular}{|c|c|c|}
\hline Type of samples & Type of test Compressive strength (MPa) & Flexural tensile strength (MPa) \\
\hline Reference concrete & 30.4 & 3.2 \\
\hline 10 \% RC replacement & 29.16 & 2.9 \\
\hline 20 \% RC replacement & 27.3 & 2.5 \\
\hline 30 \% RC replacement & 23.8 & 2.1 \\
\hline 40 \% RC replacement & 18.1 & 1.7 \\
\hline
\end{tabular}

Table 7 Physical tests of RC in sulfuric acid solution.

\begin{tabular}{|c|c|c|c|c|c|c|}
\hline Type of samples & Test type of & U.P.V. $(\mathrm{km} / \mathrm{s})$ & $\begin{array}{l}\text { Bulk density } \\
\left(\mathrm{gm} / \mathrm{cm}^{3}\right)\end{array}$ & $\begin{array}{l}\text { Water absorption } \\
(\%)\end{array}$ & Specific gravity & Porosity (\%) \\
\hline Reference concrete & & 5.33 & 2.2 & 3.98 & 2.5 & 9.07 \\
\hline 10 \% RC replacement & & 5.2 & 2.18 & 3.99 & 2.48 & 9.45 \\
\hline 20 \% RC replacement & & 4.9 & 2.08 & 4.08 & 2.44 & 10.9 \\
\hline 30 \% RC replacement & & 4.5 & 1.98 & 4.2 & 2.39 & 11.8 \\
\hline 40 \% RC replacement & & 4.1 & 1.64 & 4.31 & 2.32 & 13.09 \\
\hline
\end{tabular}

Recycled concrete aggregate replacement in amounts (10\%, 20\%, 30\% and 40\%) decreases compressive and flexural tensile strength of immerged samples in dilute sulfuric acid solution concrete, cube compressive strength and flexural tensile strength test results range respectively between 29.16 MPa 2.9 MPa for $10 \%$ replacement to $18.1 \mathrm{MPa}, 1.7 \mathrm{MPa}$ for $40 \%$ replacement as shown in Table 6, Figs. 2 and 3.

UPV test results are $5.33 \mathrm{~km} / \mathrm{s}$ for reference samples and range between $4.1 \mathrm{~km} / \mathrm{s}$ to $5.2 \mathrm{~km} / \mathrm{s}$ for recycled concrete aggregate replacement in proportions $10 \%$ to 40\% as shown in Table 7 and Fig. 4.

Bulk density test results are $2.2 \mathrm{~g} / \mathrm{cm}^{3}$ for reference samples and range between $1.64 \mathrm{~m} / \mathrm{cm}^{3}$ to $2.18 \mathrm{~m} / \mathrm{cm}^{3}$ for recycled concrete aggregate replacement in proportions $10 \%$ to $40 \%$ as shown in Table 7 and Fig. 5.

Water absorption test results are $3.98 \%$ for reference samples and range between $3.99 \%$ to $4.31 \%$ for recycled concrete aggregate replacement in proportions
$10 \%$ to $40 \%$ as shown in Table 7 and Fig. 6 .

Specific gravity test results are 2.50 for reference samples and range between 2.32 to 2.48 for recycled concrete aggregate replacement in proportions $10 \%$ to 40\% as shown in Table 7 and Fig. 7.

Porosity test results are $9.07 \%$ for reference samples and range between $9.45 \%$ to $13.09 \%$ for recycled concrete aggregate replacement in proportions $10 \%$ to 40\% as shown in Table 7 and Fig. 8.

\section{Conclusions}

The concrete samples with natural aggregate gives best mechanical and physical results for both samples cured in water and submerged in dilute sulfuric acid solutions.

The concrete samples with $10 \%, 20 \%$ and $30 \%$ partial replacement of coarse aggregate give mechanical and physical results close to reference samples cured in water.

The concrete samples with $10 \%$ and $20 \%$ partial 
replacement of coarse aggregate deterioration results in dilute sulfuric acid solution give mechanical and physical results close to reference samples submerged in dilute sulfuric acid solutions.

$30 \%$ and $40 \%$ partial replacement of coarse aggregate samples results deviates from both reference samples cured in water and submerged in dilute sulfuric acid solution.

\section{References}

[1] Young, P. C., and Teo, D. C. L. 2009. "A Utilization of Recycled Aggregate as Coarse Aggregate in Concrete." E-Journal of Civil Engineering 1 (1).

[2] Shamsulddin, Z. A. 2016. "Behavior of Recycled Construction Material Concrete Against Elevated Temperatures." In Proceedings of 4th International Conf. Sustainable Construction Materials and Technologies SCMT4, 10.

[3] Joorabchian, S. M. 2005. "Durability of Concrete Exposed to Sulfuric Acid Attack.” M.Sc. thesis, Azad Univ., Tehran, Iran.

[4] Portland Cement Association. 2002. Concrete Information Types and Causes of Concrete Deterioration. Illinois, USA: Portland Cement Association.

[5] Hanayneh, B., Shatarat, N., and Katkhuda, H. 2012. "Improving Durability of Concrete to Phosphoric Acid Attack." Jordan Journal of Civil Engineering 6 (1): 68-82.

[6] Attiogbe, E. K., and Rizkalla, S. H. 1988. "Response of Concrete to Sulfuric Acid Attack." ACI Material Journal 85 (6): 481-8.
[7] American Society for Testing and Materials C117. 2007. Standard Test Methods for Chemical Analysis of Hydraulic Cement. West Conshohocken, P.A.: ASTM International.

[8] American Society for Testing and Materials C136. 2001. Standard Test Method for Sieve Analysis of Fine and Coarse Aggregates. West Conshohocken, P.A.: ASTM International.

[9] American Society for Testing and Materials C143. 2001. Standard Test Method for Flow of Hydraulic Cement Mortar. West Conshohocken, P.A.: ASTM International.

[10] British Standard BS 1881: Part 116: 1983. Method for Determination of Compressive Strength. British Standard Institution.

[11] American Society for Testing and Materials C 293. 2002. Standard Test Method for Flexural Strength of Concrete (Using Simple Beam with Center-Point Loading). West Conshohocken, P.A.: ASTM International.

[12] American Society for Testing and Materials C597. 2002. Standard Test Method for Pulse Velocity through Concrete. West Conshohocken, P.A.: ASTM International.

[13] American Society for Testing and Materials C 642. 1997. Standard Test Method for Density, Absorption and Voids in Hardened Concrete. West Conshohocken, P.A.: ASTM International.

[14] Neville, A. M. 2005. Properties of Concrete. 4th ed. Harlow, England: Pearson Education.

[15] Saleh, S. A., Shamsulddin, Z. A., and Jasim, R. Z. 2012. "Improvement the Corrosive Strength of RC Industrial Water Exposed to Sulfuric Acid by Using Synthetic Fibers." Eng. And Technology Journal 30 (11): 259-72. 